\title{
The Understanding of Curriculum Philosophy among Trainee Teachers in Regards to Soft Skills Embedment
}

\author{
Aminuddin $\operatorname{Hassan}^{1} \&$ Marina Maharoff ${ }^{1}$ \\ ${ }^{1}$ Faculty of Educational Studies, Universiti Putra Malaysia, Selangor, Malaysia \\ Correspondence: Aminuddin Hassan, Faculty of Educational Studies, Universiti Putra Malaysia, 43400 UPM \\ Serdang, Selangor, Malaysia. E-mail: aminuddin@upm.edu.my
}

Received: August 8, 2014

Accepted: September 9, 2014 Online Published: November 26, 2014

doi:10.5539/ies.v7n12p84

URL: http://dx.doi.org/10.5539/ies.v7n12p84

\begin{abstract}
Curriculum philosophy may assist in learning practices that coincide with the philosophy of educational institution and community. This study was aimed to understand how the teacher trainees who pursued Bachelor of Teaching (PISMP) understand the embedment of soft skills into learning activities for core courses in Malaysian Institutes of Teacher Education (IPGMs). This is necessary because embedding soft skills is sometimes considered to be out of interest among the teacher trainees that may lead to neglect the aspects of soft skills development among them. The study was conducted using a case study methodology through the qualitative approach. The respondents comprised of nine teacher trainees from the final year of study. The results yielded the teacher trainees' beliefs and identified the ways soft skills were embedded among them as they pursued their course. The results of this study allowed those involved in the development of teacher trainees' soft skills to generate ideas to develop a model to embed soft skills, in line with the interpretation of soft skills, for the teacher trainees in the IPGM.
\end{abstract}

Keywords: learning, active teaching, embedding soft skills, case study, qualitative study

\section{Introduction}

Curriculum philosophy provide educators the knowledge on how students learn and what teaching methods are worthy practices, as well as the idea that learners' philosophies may evolve and continue to evolve along with personal growth and experiences (Ornstein, Pajak, \& Ornstein, 2011). Thus, the best method of soft skills embedment should be by providing the softest skills learning experience for students.

Over the past decade, there has been an increase in the number of researches that focused on soft skills and were related to the field of soft skills characteristics (AC Nielsen Research Services, 2000; Assiter, 1995; Australian Council for Educational Research, 2001b; Barrie, 2006; Beckett \& Hager, 2002; Bennett et al., 2000; Bowden et al., 2000; Clanchy \& Ballard, 1995; De La Harpe et al., 2000; Dearing Commission, 1997; Department of Education Science and Training, 2005; Drummond et al., 1998; The Association of Graduate Recruiters, 1995). Yet, despite the interest in soft skills, there is still disagreement about how soft skills can be understood, defined, used, taught, and assessed in the field of education. Interests around the world for the study have resulted in diverse definitions of soft skills and development of soft skills among university students, which are rooted in several factors broadly classified either pedagogical or socio-economic. Pedagogically, situation learning theory suggests that humans would learn more effectively in situations that may give meaning to them. Based on this reason, the embedment of soft skills in the students' study programs or relevant contexts has continued to become the focus in the development of soft skills in higher education institutes.

Harvey et al. (1997) and Te Wiata (2001) found that students' ability to integrate and develop soft skills is connected with the development of confidence to apply soft skills in a new and different context, including in the workplace. In Malaysia, the development of soft skills among university students has been prescribed by the Ministry of Education (MOE) since 2006. Until today, almost all public institutions of higher learning have implemented their own soft skills development programs, guided by the soft skills development framework as proposed by the ministry. At the same time, in the context of other efforts outside the institution, students develop personal and professional skills while staying away from their family, travelling, doing charitable work, and the community also affects their self-confidence, and as a result, these enhance the ability of their employability market (Atkins, 1999). Learning experiences can be harnessed and translated into a class through 
reflection, but usually it does not occur until it is incorporated into the learning objectives, formally evaluated, and students accept the importance of soft skills in their future career (Bennett et al., 2000).

As one of the public higher education institutions in Malaysia, the IPG of Malaysia has also started introducing soft skills into the Bachelor of Teaching (PISMP) program since 2007 with the aim of developing soft skills among teacher trainees in the institute. The IPG was also found to apply an embedding soft skills model during the implementation of soft skills into the core courses of PISMP. Core courses refer to all the compulsory courses that must be taken by all the teacher trainees of the institute as a basis for the teacher education field. This study also assumed that the property of soft skills in the teacher trainees' education is also shaped by the knowledge and discipline skills and professionalism. In the IPG context, they have already applied the embedding soft skills model in developing the teacher trainees' soft skills; therefore the researcher studied the acceptance and understanding of these teacher trainees towards the embedding soft skills model.

In the context of educational reforms study to implement a student-centred pedagogy while embedding soft skills, it is important to review the understanding and beliefs that existed among the teacher trainees. Studies on teacher trainees' learning experience are expected to contribute to the understanding of how they may, or may not change their educational beliefs. As future teachers, their understanding is very important to the implementation of the ministry's efforts to adopt a student-centred approach while embedding soft skills into the teaching and learning of core courses. Although educational change can occur at various levels, such as the individual lecturer, educational institutions, community, and country (Fullan, 2001; Richardson, 1990), the teacher trainees and teachers are considered the major agent of change and play a role in changing schools (Beck, Czerniak, \& Lumpe, 2000).

Thus, the study towards understanding the belief structures among the teacher trainees is vital to improve their learning practices, as Pratt (1998) states "beliefs and values are not small things; it is basic; beliefs and values are such as the submerged large icebergs where the specific teaching methods lies".

\subsection{Problem Statement}

The current situation shows that the soft skills teaching and learning in IPG has been stated in the Handbook of Degree in Teaching Program, in which soft skills competency is expressed as part of a holistic component in the PISMP curriculum design.

The embedding of soft skills is taught in the core courses that provides $23(17 \%)$ credits of $133(100 \%)$ overall credits in PISMP. The difference in the core courses credit is relatively small and it is the only opportunity for the teacher trainees to learn soft skills within six semesters. Moreover, there is a gap of two semesters in which the teacher trainees might miss the soft skills development process during the final two semesters, which is a very critical condition as they will very soon begin their career as real teachers.

Various research scopes of soft skills that were looked into in Malaysia focused on general concerns of graduate soft skills level (Ng et al., 1994; Shaharuddin et al., 2010), meanwhile, Ali et al. (2012) and Roselina (2009) state that soft skills are usually difficult to observe, measure, and evaluate. Hence, it is important to ensure that soft skills are understood and accepted by the students so that the principles of soft skills can be practiced by them in future. Thus, the soft skills development process through formal teaching and learning is very significant to enable students to develop their soft skills effectively.

Therefore, this study aimed to find a common ground between the short period of embedding soft skills and the difficulty in understanding the soft skills with belief among the teacher trainees about soft skills embedded during their study period. Since the embedding of soft skills occurs in tandem with the teaching and learning process, in order to review the embedding of soft skills, the aspects of teaching and learning are also discussed because, although soft skills are still regarded as the hidden curriculum, it has gained a place and become a priority agenda in providing the human capital for the future.

\subsection{Purposes of the Study}

While the ministry has made the embedding soft skills model as one of the approaches to develop soft skills in the higher education institutions, researches have shown that there are differences of acceptance and understanding towards the approach. Thus, the objectives were to:

Understand how the teacher trainees understand the embedding of soft skills through core courses learning.

Understanding the relationship between the teacher trainees' perceptions towards the embedding of soft skills with their actual learning practices. 


\section{Literature Review}

The higher education institute soft skills development programs have generally been introduced by one of the two or a combination of both bolt on and embedded models (Kementerian, 2010; Roselina, 2009). The bolt on model was identified by Dunne (1995), while the embedded model might provide an opportunity for soft skills elements to be delivered as part of the core courses (Chaple \& Tolley, 2000).

Through the bolt-on model of soft skills subject, the teaching and learning of soft skills run in parallel with the current core courses. The advantage of this model is the ability to introduce soft skills without making changes to the core courses curriculum. However, the weakness of this model is in the development of soft skills at out of the context, because there are some opportunities for the transfer of soft skills to occur (Bennett et al., 2000).

Based on the literature, the embedded model was found to be able to be implemented across the formal teaching and learning activities, thus the model applied should be focused on its advantages in helping students through the learning process, providing an opportunity for practical experience, and focusing on the student-centered learning approach.

Studies within Malaysia about soft skills are similar to studies conducted abroad in terms of success in the implementation of soft skills (if there is no problem), but fewer reports or studies have been found about the ways of teaching and learning of soft skills into the current formal curriculum. A compilation of research results related to soft skills in the higher education institutions by Ahmad and Mohammad-Zaid (2010) indicates the scope of the soft skills studies that have been conducted in Malaysia were mainly focused on the profile of soft skills for graduates, students, and teachers, compared to the teaching and learning process of soft skills. The lack of reports or studies on teaching and learning methods of soft skills into the teacher training curriculum might create a gap of difficulties in developing soft skills among the teacher trainees. There are concerns that the situation will persist until these teacher trainees become school teachers, as the findings by Wan-Azlinda and Mohamed-Hafis (2009) found that teachers also have found difficulties to embed the soft skills competencies to students due to lack of understanding related to soft skills.

Bowden et al. (2000) stated that soft skills should be related to the content of learning or discipline of study explicitly rather than implicitly. The main practices that need to be addressed are by embedding soft skills competency in the curriculum disciplines. Findings from studies consistently showed soft skills competency in higher education are more effectively developed in the context of discipline knowledge, inculcated into the curriculum (embedding model) rather than through bolt-on model (stand-alone subject), which is isolated from the context of discipline (Barrie, 2004; Bath et al., 2004; Bowden et al., 2000; Drummond et al., 1998; Star \& Hammer, 2007; Sin \& Reid, 2005; Thompson et al., 2008). The isolation of soft skills from a disciplinary learning environment might be at risk of shallow technical approaches of teaching and learning of soft skills (Star \& Hammer, 2007).

\section{Methodology}

This study adopted a constructivist paradigm to guide the researcher as the qualitative methodology was used to investigate the learning experiences among teacher trainees. The constructivist paradigm is fundamental for qualitative research methods (Guba \& Lincoln, 1994). This study used a qualitative inquiry because it uses a naturalistic approach that seeks to understand phenomena in the context of a specific environment, such as "real-world environment (where) the researchers did not attempt to manipulate the phenomenon under study" (Patton, 2002).

The emphasis on the uniqueness of the individual and focus on understanding the participants from their own perspective have led to the use of case studies. According to Merriam (1998), a case study is an intensive, holistic description, and an analysis of a single unit or limited system. Yin (2003) defines a case study as an empirical inquiry that investigates a contemporary phenomenon in a real life context, especially when the boundaries between phenomenon and context are not clear.

A case study approach was used in this study to look into the embedding of soft skills into core courses learning in one of the IPGs in Malaysia. The case study was IPG's (bounded system) to explore the learning experience of teacher trainees.

Before the recruitment of the participants started, the researcher established clear criteria for the selection of participants, in which all the teacher trainee participants were studying PISMP and she/he is a final year student who had taken all the subjects for the core courses.

Nine teacher trainees were involved in this study. The reliable sample size was sufficient because the answers during the interview provided saturated data, which were diverse, dense, and deep that allowed the researcher to 
explore the views and experiences of their core courses learning.

Individual semi-structured interviews were used as the primary source of evidence. It was later supported and triangulated with other sources, such as document analysis, focus group interviews, and stimulated recall interviews.

In this study, the researcher used the M \& H's Interaction Model for Qualitative Data Analysis (Miles \& Huberman, 1994) to analyze the internal data and in each source of the data (individual interviews, focus group interviews, and stimulated recall interviews). This model showed that data analysis involved three interrelated activities and it started with data collection. These activities were data reduction, data display, and making conclusions and verification. The strategy for analyzing the data was referred to the three stages: 1) manually, 2) the use of Atlas.ti software, and 3) interpretation of data.

\section{Findings and Discussion}

Through qualitative data analysis, as outlined by Miles and Huberman (1994) and with the assistance of Atlas.ti software to analyze data from individual interviews of participants and focus group interviews, four themes were identified. The four themes highlighted many academic and logistical complexities of the learning experiences of the participants. These themes involved issues in traditional learning through direct instruction, active engagement in learning activities in the classroom, individual responsibility in the learning process, and the influence of embedding soft skills into learning.

\subsection{The First Theme: Traditional Learning by Direct Teaching}

The teacher trainees related their understanding about the traditional learning methods with direct teaching, such as lectures. They reported that direct teaching as one of the approaches to promote content mastery learning among the teacher trainees. This is because lectures have the advantages that will be discussed next.

a) The Lecture Content is More Compact and focused

Some participants reported that they preferred direct teaching like lecture, as long as the lecturers knew how to attract attention from the teacher trainees, "I can concentrate well when the lecturers give lectures directly in a way that is easy and relaxed, not too complex or too stressed to the course content..." (Yahya). Norazurah also agreed and believed that the traditional live lectures were effective when the lecturers were knowledgeable in their field and know how to attract the interest of students in the class.

They are very knowledgeable in their field and know how to make students remember and can concentrate on what is being taught. Sometimes, the lecturer stopped during the lecture and started questioning us about what he had described earlier ... sometimes hilarious lecturers do make classes more fun and cheerful ... (Norazurah)

b) More Information Means More Understanding

The teacher trainees also said that as long as the lecturer can give them better understanding of the subjects taught, they do not worry about the approach used. During the focus group interview, Astuty expressed her opinion on this issue;

Although I love facilitative teaching strategies, such as group work and field work, I prefer the traditional teaching approach because I can focus on the lesson being taught and I can understand better. I do not care about the teaching methods used by the lecturers as long as I can understand the lesson ... for me, understanding is very important in learning... without understanding I cannot study well and how could I answer well in the exam later? Through lectures, I can have more information; more information means better understanding ... (Astuty)

The feedback from Astuty above reflected her belief that learning must be coupled with explanation because it gave them better understanding. This suggests a belief that lecturers should be very knowledgeable in their subject disciplines to deliver learning content.

c) Learn From the Experts

Some participants expressed that the traditional approach were often taught by lecturers who were very knowledgeable in the subject matter. Reactions from participants found to be influenced by the way they accepted lectures as experts in the context of the lecturer-teacher trainee relationship in the learning situation. The teacher trainees' perceptions may be bound to the culture as Malaysian students believe that the teacher (lecturer) is the expert. During the individual interviews and focus group interviews, the participants expressed that a lecturer must be an expert to teach them. They defined the expert lecturers as someone who are very knowledgeable in the subject content and not necessarily an expert in how to teach. During the individual 
interviews, Zuwita said if she were given the opportunity to choose either a lecturer based on knowledge or teaching approach, she would choose a knowledgeable lecturer. This suggests her belief about knowledge and content as the key elements in learning compared to teaching methodology.

On the other hand, some of the participants reported some of the advantages of learning from experts through direct teaching as they mentioned the weaknesses behind direct teaching (lecture). Yahya reported that normally interaction with lecturers is difficult during lectures.

...sometimes even the way lecturers communicate make us think that they are experts in their field, and therefore, we have no right to interfere in their teaching approach... although we have the same idea, but the truth is it is very difficult to interact with them... furthermore lecturers are busy with lectures, and in fact they have no time to interact with students ... (Yahya)

d) Learning through Memorization

The data from the focus group interviews with the teacher trainees suggested that they identified memorization as a strategy for them to learn. They reported that they memorized as a first step to understand their lessons.

I did memorize, especially when there are facts or data that I need to remember... there are certain facts that are difficult to understand during lecture, but through rote, I can understand what I felt difficult in the previous class... By entering the knowledge into books or lecture notes into my head, it can help me understand... (Zetty)

The feedback from some participants about memorization proposed their view that memorizing facts allowed them to reflect on it in the future and to assist them in integrating the facts with their previous learning and experience. This suggests that as for the teacher trainees, their rote learning strategies is not superficial learning or solely preparation for excellence in the exam, but it is a profound learning which helped them to understand and answer exams better. Deep learning focuses on an understanding of the subject matter by one way of linking different topics together and information processing, rather than superficial learning that focuses on producing something without understanding.

\subsection{The Second Theme: Involvement in Active Learning Strategies}

Despite the positive comments about the participants' passive learning, the data also showed that they appreciated active learning approaches in their learning. Active learning is a learning strategy that emphasizes participation and ownership of students on the subject matter and encourages reflection activities by individuals as part of the learning process. As for the teacher trainees who were familiar with the traditional learning environment during their initial education in schools, the active learning approach used by the lecturers is to shift the teacher trainees from being solely lecture listeners to active participants. Active participants would be in line with student-centered learning strategy, whereby active strategies, such as collaborative learning, in-class presentations, project-based learning, and self-learning were practiced. This suggests that active learning is an interactive aspect of lecturers' teaching styles and learning strategies for the teacher trainees.

As for Nazim, although he preferred direct teaching methods, he still needed interaction with the lecturer. Nazim reported the distance in relationship he felt from lecturers who used the lecture approach. Nazim further commented that often, the lecturers gave lectures that were quite distressed to finish the lecture contents without thinking about any interaction with the teacher trainees. Due to this, Nazim said that he would prefer to learn from lecturers who used active learning strategies combined with direct lectures. Nazim explained how he was able to interact with the lecturers through participation in class activities compared to attending lectures. This suggests that despite the acceptance of the traditional direct teaching passively, the participants also like to actively participate in class activities provided by some lecturers.

a) Improve soft skills through active learning

Most of the participants found that through participation in active learning strategies, they developed the skills from learning. They reported that through active learning, they could use the information and new skills instantly, "outdoor activities gave me some useful knowledge and skills that are not available in the classroom. I learned the real situation and related issues ..." (Norazurah).

Some participants reported that active learning strategies can improve their skills and communication competencies in areas such as leadership. Here are the dialogues among the members of the group to focus on this issue:

I think I prefer to be actively involved in learning activities in the classroom when the subject of study is to make us think. From these activities, it will allow us to think creatively and critically in solving problems, and at the same time, we can build other skills, such as communication skills, group management skills and others... 


\section{(Nazim)}

I also agree that classroom activities are good, and sometimes, the management activities like project in Bina Insan Guru, gives a lot of benefits to me. I was able to learn more about how to socialize and conduct formal communication with the authorities. That is a skill that we do not learn in the classroom... (Astuty)

b) Active learning for teaching careers in the future

The data from the individual interviews and focused group interviews revealed that the participants believed that active strategies, such as discussions, self-learning, and presentations in the classroom, were effective learning approaches, especially since they played a role in shaping their teaching practice in the future. During the focus group interview, Harun and Yahya stated;

As future teachers, we need to know the new teaching and learning strategies... such as self-directed learning, problem solving, reflection and other thoughts. That way when we become teachers, we will know how to use these strategies effectively in our own teaching practices and can help students learn better. That's why I like to use all the strategies now... (Yahya)

I should be active in the classroom. Furthermore here (IPG), I get a lot of opportunities to be active in the classroom. Most lecturers use active learning strategies as their teaching approaches. Maybe some students are more active and more dominant in the class, but the lecturer actually give equal opportunity to all students to participate. Everything is up to us. I would use the same method when I became a teacher later so that my students can learn better ... (Harun)

The feedback indicates that the participants were sensitive and viewed teaching as a training effort for their future employment.

\subsection{The Third Theme: Responsible for Self-Learning}

The third theme that emerged from this research was the teacher accountability for their self-learning. Responsible teacher trainees performed academic tasks without constantly reminded on a regular basis by lecturers. This supports the statement of the student-centered learning. The findings indicated that the teachers accepted active learning elements approach that emphasizes the accountability of the participants to determine what and how to learn so that they can play an active role in their learning.

This theme reflected some aspects in developing self-reliance among the teacher trainees. Thus, the participants were aware of their responsibility to be active teachers, but not passive.

a) The teacher trainees' autonomy

The evidence from individual and focus group interviews showed that most participants preferred to be active participants and have the autonomy in the learning process. The data revealed that most of the participants considered themselves playing an active role in the learning process, "we need to be active and know how to monitor self-learning process ..." (Nazim) and "we learn actively to determine what we need to know... to achieve success" (Faraliza). In an interview excerpt, Zetty reflected other views on teacher trainees' autonomy,

During group discussions, we often choose our own goals and objectives of our topic. Then we can define objectives and select the material that we feel appropriate to our topic... we also have the power to determine the methods and tasks appropriate to the topic... then we should be responsible for carrying out the method and the task we have chosen... (Zetty)

Harun stated that he is an independent thinker when playing the role of an active participant. He explained that he needed to give opinion to others in order to build more relationships between the existing knowledge with new knowledge, "I prefer to be an independent thinker and discover that I can express my own views on any matter..." (Harun).

On the other hand, a few participants reported that they had autonomy over their role in active learning; Nazim revealed how he believed active strategy empowered him to make his own decision. This seems to indicate that autonomy and power are the same. He mentioned that he "can make decisions about the best ways of learning, resources, and structures needed to take over the activities in the classroom" provided by the lecturers. Norazurah added that she could make her own decisions in terms of learning resources, "Students have a great responsibility to find other alternatives if they do not understand (lesson) from a particular lecturer. I always make my own decisions about learning resources... "(Norazurah).

Some participants reported that they became more creative and critical thinkers when they were active participants, "I know that by being active during learning, it will help me to think more creatively and 
critically..."(Faraliza). They were willing to find and process information on their own, "the lecturer allows us to interpret and make reflection to be more creative and critical on the lesson... and we can build our own learning" (Astuty).

b) Finding and creating meaning actively

According to the constructivist learning theory, new knowledge arises from the individual active meaning construction resulting from unique experience and prior knowledge. The initial experience and knowledge of the teacher trainees can be considered as prior learning. The data showed that the participants were given the opportunity to actively seek and build their own meaning of the subjects studied. Some participants described how their lecturers adopted active teaching strategies to help them relate new knowledge to prior knowledge. They explained that through a variety of learning activities in the classroom, the lecturers encouraged them to lay out their prior knowledge by asking them to explain, how they think, and shape their responses by linking them to the previous learning. The participants also mentioned that the lecturers helped them to draw conclusions about what they had learned and helped them to apply it to a new situation by integrating new information with what they had already known.

They reported that through active learning strategies, such as project-based learning, self-learning, and presentations in the classroom, the lecturers actually provided the opportunity for the teacher trainees to issue their experiences and interpretations.

Findings to this study showed that some of the participants developed their meaning of learning situations through opportunities to integrate previous learning with the new learning. Faraliza stated that the lecturer asked her to "try to find a link" between "what was known with the new content material". Julaiha explained that the lecturers encouraged her to formulate what she knew when the lecturers said "build a creative relationship between your foreknowledge with something new".

\subsection{The Fourth Theme: The Impact of Embedding Soft Skills to Learning}

The fourth theme that emerged from the data analysis of the study was the impact of the embedding soft skills on the participants' learning approach. Some of the participants' views on the use of active learning were based on their beliefs and views on the embedding of soft skills. This reflected the philosophy of their teaching and learning. Some related their active involvement in a variety of strategies in the classroom to the embedding soft skills philosophy where there were corresponding elements between the active learning strategy and the perspective of embedding soft skills.

a) Embedding soft skills turn us to be an active learner

During the focus group interview, Yahya said that soft skills development required active learning methods. From the perspective of embedding soft skills, the teacher trainees were encouraged to develop and defend arguments based on education issues clearly and coherently. Yahya related his transformation from passive learning to active learning with the philosophy of embedding soft skills, "Embedding soft skills requires students to develop their soft skills by a way to do it, to do so, students need to be active" (Yahya). This shows that his teaching and learning perspective was influenced and parallel with his beliefs about embedding soft skills.

I believe that education is not merely the process of obtaining information, where the lecturers impart knowledge that can be absorbed by the students. Instead, it is the construction of knowledge in how to do it or practice as required in the embedding of soft skills. This means that as students, we must be active in the process of learning to make learning more meaningful... the embedding of soft skills requires us to be active students and not just passively waiting to absorb knowledge from lecturers... (Yahya).

b) The importance of knowledge acquisition and active doing

Faraliza associated her beliefs about learning with the embedding soft skills philosophy, which emphasized the importance of knowledge and skills. She stated that learning should involve both the acquisition and construction of knowledge and skills.

Learning is effective only when it is practiced, not just memorizing the information, the embedding of soft skills need us to be active... so as students, we need to be active to practice the knowledge and skills. For example, participation in various activities provided by lecturers in the classroom... through participation in activities in the classroom, students will feel they are appreciated and respected by lecturers... furthermore, lecturers are encouraged to build good relationships with students, so when lecturers ask us to do something in the classroom, we need to participate... (Faraliza)

Faraliza reported that in her teacher training, she was introduced to the elements of soft skills. Zetty also related 
her understanding about learning from the perspective of embedding soft skills. For Zetty, teachers must be active in learning and to address the challenges ahead for the embedding of soft skills requires them to be active.

We must be active in learning, engaging in class activities, trying to solve any task given by lecturers... although some tasks are quite difficult and complicated, but we have to accomplish them until they are successful, we need to manage work wisely, those are what needed in embedding soft skills... (Zetty)

Similarly, another participant, Julaiha, was guided by the embedding soft skills philosophy when she related the role of a teacher trainee as an active learner.

As teacher trainees, we must be active learners to explore the broader relationship between the knowledge and skills we learnt, not just memorize the parts of knowledge in isolated way. By being active, we can focus on the important aspects, not only those that cover superficial teaching ... (Julaiha)

Besides, the feedback from Yahya during an interview showed that he saw himself as a constructor of knowledge, as emphasized in the philosophy of embedding soft skills.

As students, we are constructors of knowledge, even if we accept the knowledge from lecturers, we still have a role to play, and we need to find information, evaluate learning, and generate new ideas of our own. Embedding soft skills emphasize both the construction and practice of the skills learned ... (Yahya)

All the above feedback shows that the participants assessed their roles actively and had responsibility in developing knowledge, and were in line with the philosophy of embedding soft skills. They acknowledged that active learning as appropriate to the embedding soft skills approaches.

\section{Conclusion}

The formal approach to overcome the problem of embedding soft skills can be done by integrating soft skills competencies into the curriculum of a program (Schulz, 2008). This study suggested the influence of embedding soft skills in teacher trainees' learning. The teacher trainees were involved in this study related the embedding of soft skills to their teaching and learning. This highlights the teaching and learning as a process that mediated the context of embedding soft skills.

Over the years, educators have understood that learning is shaped by changes in behavior and the acquisition of knowledge, but Visser (2008) defines learning as a condition of human thought and social entities that engage them, to engage in continuous dialogue with the human, social, biological, and physical environment, to generate intelligent behavior, and to interact constructively with change.

Learning is that to be used up to the most comprehensive level, requires the development and monitoring of the thinking throughout human life with the purpose of engaging in the dialogue with the environment and interacting with constructive environment changes of someone (Visser, 2008). The study of what and how students learnt in the higher education institutions should be taken seriously by academics (Laurillard, 2002). According to Laurillard (2002), another common method of supporting learning in the higher education institutions is through the acquisition of information, practice, discussion, and study.

However, the impact of the 'information society' has led to both the nature of knowledge and how knowledge is acquired to change (Nunes \& McPherson, 2003). Even higher learning institutions have often focused on producing inert knowledge and abstract concepts, which become useless if students do not understand how to use them in the right situations (Grabinger \& Dunlap, 1995; Nunes \& McPherson, 2003). Grabinger and Dunlap (1995) have listed the weaknesses in teaching approaches that contribute to the production of inert knowledge in institutes of higher learning.

The findings are in line with the perspective of embedding soft skill by Bowden et al. (2000) and Jones (2009a, $2009 \mathrm{~b}, 2010)$. In their view, the embedding of soft skills is not just delivering what the soft skills are, the importance of soft skills as soft skills elements are paramount etc., but it is more on developing soft skills in students by relating it with their future career. This can be achieved by means of the lecturers themselves by providing opportunities for the teacher trainees to practice soft skills during their teaching and learning process.

This study reported some issues about the perspectives and experiences of some teacher trainees towards the embedment of soft skills in teaching and learning. A lot of questions arose during this study. Due to the limitations of this study, it is suggested that studies in the future can make comparisons about the relationship between strategies in embedding soft skills with teaching approaches by lecturers and learning approaches by the teacher trainees. This is due to the comprehensiveness in embedding soft skills that is dealt with both student-centered teaching and learning approach by the lecturers and the teacher trainees. Thus, teaching and curriculum are interwoven in learning practices and it may reflect the institution and community philosophy. 


\section{References}

AC Nielsen Research Services. (2000). Employer Satisfaction with Graduate Skills. Department of Education. Canberra: Higher Education Division.

Ahmad, E., \& Muhamad-Zaid, M. (2010). Kemahiran insaniah: Kajian di institusi-institusi pengajian. Batu Pahat, Johor: Penerbit UTHM.

Ali, F. A., Long, Y., Zainol, F. A., \& Mansor, M. (2012). Student's Self-perceived Importance of Employability Skills Needed: A Case Study in University of Sultan Zainal Abidin (UniSZA), Malaysia. 2nd International Conference on Management (pp. 1038-1054). Kuala Lumpur.

Assiter, A. (1995). Transferable Skills in Higher Education. London: Kogan Page.

Atkins, M. (1999). Oven-ready and self-basting: Taking stock of employability skills. Teaching in Higher Education, 4(2), 267-278.

Australian Council for Educational Research. (2001). Graduate Skills Assessment. Department of Education, Training and Youth Affairs. Canberra: Higher Education Division.

Barrie, S. (2006). Understanding what we mean by the generic attributes of graduates. Higher Education, 51(2), 215-241.

Barrie, S. C. (2004). A research-based approach to generic graduate attribute policy. Higher Education Research and Development, 23, 261-275.

Bath, D., Smith, C., Stein, S., \& Swann, R. (2004). Beyond mapping and embedding graduate attributes: Bringing together quality assurance and action learning to create a validated and living curriculum. Higher Education Research \& Development, 23, 313-328.

Beck, J., Czerniak, C. M., \& Lumpe, A. T. (2000). An exploratory study of teachers' belief regarding the implementation of constructivism in their classrooms. Journal of Science Teacher Education, 11(4), 323-343.

Beckett, D., \& Hager, P. (2002). Life, Work and Learning: Practice in Postmodernity. London : Routledge.

Bennett, N., Dunne, E., \& Carré, C. (2000). Skills Development in Higher Education and Employment. Buckingham: SRHE \& Open University Press.

Bowden, J., Hart, G., King, B., Trigwell, K., \& Watts, O. (2000). UTS: Institute of interactive media of learning. Retrieved October 23, 2012, from http://www.iml.uts.edu.au/curriculum/index.html

Chaple, M., \& Tolley, H. (2000). Embedding key skills in higher education. In S. Fallows (Ed.), Integrating key skills in higher education: Empoyability, transferable skills and learning for life. London: Kogan Page.

Clanchy, J., \& Ballard, B. (1995). Generic skills in the context of higher education. Higher Education Research \& Development, 14, 155-166.

De La Harpe, B., \& Radloff, A. (2000). Helping academic staff to integrate professional skills. In S. Fallows (Ed.), Integrating key skills in higher education: Employability, transferable skills and learning for life (pp. 165-174). London: Kogan Page.

Dearing Commission. (1997). Higher Education in the Learning Society: National Committee of inquiry into Higher Education. London: HMSO.

Department of Education Science and Training. (2005). Our Universities: Backing Australia's Future. Canberra: Common Wealth of Australia.

Drummond, I., Nixon, I., \& Wiltshire, J. (1998). Personal Transferable Skills in Higher Education: The Problems of Implementing Good Practice. Quality Assurance in Education, 6(1), 19-27.

Dunne, E. (1995). Personal transferable skills: Final report. Exeter: University of Exeter.

Fullan, M. (2001). The new meaning of educational change (3rd ed.). New York, NY: Teachers College Press.

Grabinger, S. R., \& Dunlap, J. C. (1995). Rich Environments for Active Learning: A Definition. Association for Learning Technology Journal, 3(2), 5-34.

Guba, E. G., \& Lincoln, Y. S. (1994). Competing paradigms in qualitative research. In N. K. Lincoln (Ed.), Handbook of qualitative research (pp. 105-117). Thousand Oaks, CA: Sage.

Harvey, L., Moon, S., \& Geall, V. (1997). Graduates'Work: Organisational Change and Students' Attributes. 
Birmingham: Centre for Research into Quality.

Jones, A. (2009a). Redisciplining generic attributes: The disciplinary context in focus. Studies in Higher Education, 34(1), 85-100.

Jones, A. (2009b). Generic attributes as espoused theory: The importance of context. Higher Education, 58(2), 175-191. http://dx.doi.org/10.1007/s10734-008-9189-2

Jones, A. (2010). Generic Attributes in Accounting: The Significance of the Disciplinary Context. Accounting Education, 19(1-2), 5-21. http://dx.doi.org/10.1080/09639280902875523

Kementerian, P. T. (2010). Modul pembangunan kemahiran insaniah (soft skills) untuk Institusi Pengajian Tinggi Malaysia. Serdang: Universiti Putra Malaysia.

Laurillard, D. (2002). Rethinking University Teaching: A Framework for the Effective Use of Learning Technology. Abingdon: Routledge Falmer.

Merriam, S. B. (1998). Case study research and case study applications in education. San Francisco, CA: Jossey-Bass.

Miles, M. B., \& Huberman, A. M. (1994). Qualitative data analysis: An expended sourcebook. Thousand Oaks, CA: Sage.

Nunes, M. B., \& McPherson, M. (2003). Constructivism vs. Objectivism: Where is Difference for Designers of eLearning Environments? The 3rd IEEE International Conference on Advanced Learning Technologies (ICALT'03). IEE COMPUTER SOCIETY.

Ornstein, A. C., Pajak, E. F., \& Ornstein, S. B. (2011). Contemporary Issues in Curriculum (5th ed.). Boston: Allyn \& Bacon.

Patton, M. Q. (2002). Qualitative evaluation and research methods (3 ed.). Thousand Oaks, CA: Sage.

Pratt, D. (1998). Alternative frames of understanding. Five perspectives on teaching and learning in adult and higher education. Malabar, FL: Krieger Publishing Co.

Richardson, V. (1990). Significant and worthwhile change in teaching practic . Educational Researcher, 19(7), 10-18. http://dx.doi.org/10.3102/0013189X019007010

Roselina, S. (2009). Soft skills at Malaysian institute of higher learning. Asis Pacific Education Review, 309-315. http://dx.doi.org/10.1007/s12564-009-9038-8

Schulz, B. (2008). The importance of soft skills: Education beyond academic knowledge. NAWA Journal of Language and Communication, 146-154.

Shaharuddi, A., Noriah, M. I., Khaidzir, I., \& Jumali, S. (2010). A Case Generic Competency Profile Among Students in Institute of Higher Learning of Universiti Kebangsaan Malaysia (UKM), Malaysia. Proquest Education Journal, 811.

Sin, S., \& Reid, A. (2005). Developing generic skills in accounting: resourcing and reflecting on trans-disciplinary research and insights. Annual Conference for the Association for Research in Education (pp. 1-22). Parramatta, NSW: Coldstream, VIC: Australian Association for Research in Education.

Star, C., \& Hammer, S. (2007). Teaching generic skills: Eroding the higher purpose of universities, or an opportunity for renewal? Oxford Review of Education, 34, 237-251.

Te Wiata, I. (2001). A big ask: To what extent can universities develop useful generic skills? In C. K. F. Bevan (Ed.), Knowledge Demands for the New Economy (pp. 290-297). Brisbane: Australian Academic Press.

The Association of Graduate Recruiters. (1995). Skills for Graduates in the 21st Century. Cambridge: The Association of Graduate Recruiters.

Thompson, D., Treleaven, L., Kamvounias, P., Beem, B., \& Hill, E. (2008). Integrating attributes with assessment criteria in business education: Using an online assessment system. Journal of University Teaching \& Learning Practice, 5(1), 32-48.

Visser, J. (2008). Constructive Interaction with Change: Implications for Learners and the Environment in which They Learn. In J. V. Visser-Valfrey (Ed.), Learners in a Changing Learning Landscape: Reflection from a Dialogue on New Roles and Expectations (Vol. 12, pp. 11-35). USA: Springer.

Wan-Azlinda, M., \& Mohamed-Hafis, Y. (2009). The inculcation of generic skills among juveniles through Technical and Vocational Education. US-China Education Review, 6(4), 56-62. 
Yin, R. (2003). Case study research: Design and methods (3rd ed.). USA: Sage Publication.

\section{Copyrights}

Copyright for this article is retained by the author(s), with first publication rights granted to the journal.

This is an open-access article distributed under the terms and conditions of the Creative Commons Attribution license (http://creativecommons.org/licenses/by/3.0/). 